\title{
Characterization of upper respiratory tract isolates from children with recurrent
}

\section{tonsillitis}

\section{Caracterização de isolados do trato respiratório superior de crianças com amigdalite recorrente}

Caracterización de aislamientos del tracto respiratorio superior de niños con amigdalitis recurrente

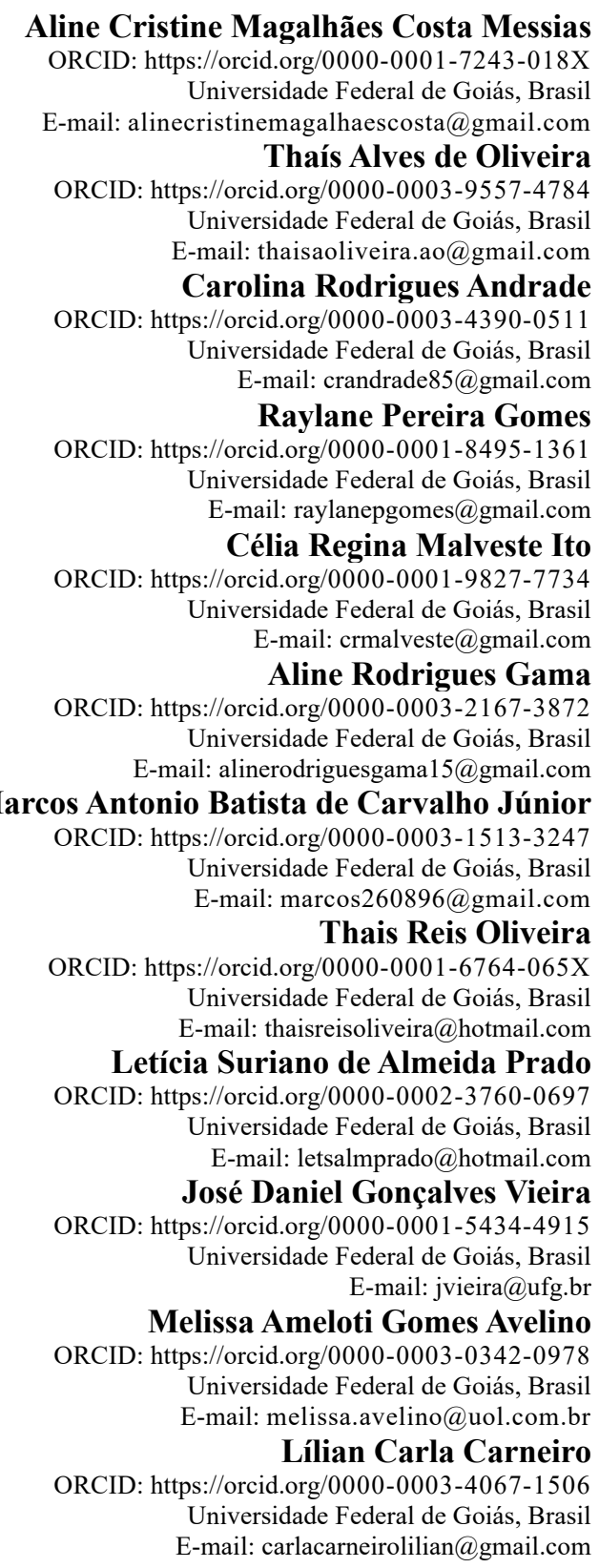

\begin{abstract}
To analyze the profile of airway Upper Respiratory Tract isolates from children with recurrent tonsillitis. Samples were taken using nasal cavity, oropharynx and nasopharynx swabs from 30 children called the test group before tonsillectomy. Counting, isolation, identification and sequencing of the $16 \mathrm{~S}$ rRNA, biofilm production and antimicrobial sensitivity investigation were performed. Staphylococcus aureus $(S$. aureus) was the only microorganism recovered in $36.6 \%$ of patients, being more present in the oropharynx and with greater resistance to
\end{abstract}


erythromycin $95 \%$, penicillin $85 \%$ and cefoxitin $85 \%$. All isolates were formed by biofilm, $20 \%$ formed by strongly adherent biofilm. $S$. aureus resistant and biofilm formed, were isolated in the three studied sites, suggesting that this species contributes to recurrent tonsillitis. Impact of the study: The ability of $S$. aureus to acquire resistance and its other associated factors such as biofilm formation, can make this microorganism recover more easily in the microbiota of patients, taking into account the other microorganisms present there after the use of antibacterial.

Keywords: Otorhinolaryngology; Recurrent tonsillitis; Staphylococcus aureus.

\section{Resumo}

Analisar o perfil de isolados do trato respiratório superior das vias aéreas de crianças com amigdalite recorrente. As amostras foram coletadas usando esfregaços da cavidade nasal, orofaringe e nasofaringe de 30 crianças chamadas de grupo de teste antes da amigdalectomia. Foram realizados contagem, isolamento, identificação e sequenciamento do rRNA 16S, produção de biofilme e investigação de sensibilidade antimicrobiana. Staphylococcus aureus (S. aureus) foi o único microrganismo recuperado em $36,6 \%$ dos pacientes, estando mais presente na orofaringe e com maior resistência à eritromicina $95 \%$, penicilina $85 \%$ e cefoxitina $85 \%$. Todos os isolados foram formados por biofilme, $20 \%$ formado por biofilme fortemente aderente. $S$. aureus resistente e biofilme formado, foram isolados nos três locais estudados, sugerindo que esta espécie contribui para tonsilites recorrentes. Impacto do estudo: A capacidade do $S$. aureus em adquirir resistência e seus demais fatores associados, como a formação de biofilme, podem fazer com que este microrganismo se recupere mais facilmente na microbiota dos pacientes, levando em consideração os demais microrganismos ali presentes após o uso do antibacteriano.

Palavras-chave: Amigdalite recorrente; Otorhinolaryngology; Staphylococcus aureus.

\section{Resumen}

Analizar el perfil de aislamientos del tracto respiratorio superior de la vía aérea de niños con amigdalitis recurrente. Se tomaron muestras usando hisopos de cavidad nasal, orofaringe y nasofaringe de 30 niños llamados el grupo de prueba antes de la amigdalectomía. Se realizó el recuento, aislamiento, identificación y secuenciacióndelrRNA16S, producción de biofilm e investigación de sensibilidad antimicrobiana. Staphylococcus aureus (S. aureus) fue el único microorganismo recuperado en el $36,6 \%$ de los pacientes, estando más presente enla orofaringe y conmayorresistencia a eritromicina $95 \%$, penicilina $85 \%$ y cefoxitina $85 \%$. Todos los aislamientos fueron formados por biofilm, $20 \%$ formado por biofilm fuertemente adherente. S. aureus resistente y formado biofilm, fueron aislado sen los tres sitios estudiados, lo que sugiere que esta especie contribuye a la amigdalitis recurrente. Impacto del estudio: La capacidad de $S$. aureus para adquirir resistencia y sus otros factores asociados como la formación de biopelículas, puede hacer que este microorganismo se recupere más fácilmente en la microbiota de los pacientes, teniendo en cuenta los demás microorganismos allí presentes tras el uso de antibacterianos

Palabras clave: Amigdalitis recurrente; Otorrinolaringología; Staphylococcus aureus.

\section{Introduction}

The microbiota of a site is defined by the presence of microorganisms and their metabolites present in the different sites of the host (Thursby and Juge2017). Each site has its own microbiota, with specific species(Coyte et al., 2015). The airway Upper Respiratory Tract (URT) is divided into two parts, the upper and the lower and, each of these sites has a specific microbiota, the URT microbiota is distinct from each other and has patterns of colonization and succession. Since early childhood, URT has been colonized by bacterial species of different genera, such as Streptococcus spp., Haemophilus spp., Coagulase negative Staphylococcus, Streptococcus viridans, Haemophilusinfluenzae, Streptococcus pneumoniae, Moraxella catarrhalis and Staphylococcus spp. (Round and Mazmanian 2009; Johnston and Douglas, 2018).

Respiratory tract infections are described when they affect the respiratory tract, both upper and lower, in which there is obstruction of the air passage, both at the nasal and pulmonary levels (World Health Organization 2014) being a major concern worldwide, as they are responsible for high morbidity and mortality, especially in children and the elderly(de Steenhuijsen Piters et al., 2015). Although frequent, when infection occurs in URT, they usually do not cause death, but significantly interfere with the individual's quality of life, in addition to generating costs for the country's health (World Health Organization 2014).

The Department of Information Technology of the Unified Health System (DATASUS) recorded that during 10 years (2009 to 2019), 13,030,947 patients were hospitalized due to respiratory diseases. Of this, 553,511 were individuals affected by 
chronic diseases of the tonsils and / or adenoids. Children are the patients most affected by tonsillitis and may have acute or chronic illness (Brazil 2020).

Palatine tonsils are aggregates of lymphoid tissue, located in the oropharynx (Lima et al. 2015), in certain circumstances, infections called tonsillitis can occur (Georgalas et al., 2014). In addition to viral conditions, tonsillitis can also develop as a result of opportunistic bacterial infections, caused by bacteria from the microbiota itself: ß-hemolytic Streptococcusof group A, Staphylococcus aureus(S. aureus) and Haemophilusinfluenzae (Wang et al., 2017).

Repetitive tonsillitis can occur due to the predominance of Gram-positive bacteria, which produce biofilm, among which is S. aureus (Torrettaet al. 2016). In addition to treatment failure due to the presence of resistant bacteria and, the acquisition of resistance to antibacterials (Nejashmikjet al. 2017; Cavalcanti et al., 2019).

A study conducted in Belgium showed that the nasal cavity of $20 \%$ of the population is persistently colonized byS. aureus, considered one of the main sites for the spread of the bacteria in URT (Sivaraman et al., 2009). It is believed that 30\% of individuals who develop infection with S. aureus in the nasopharynx, are due to bacterial migration from one site to another (Jiménez-Truque et al., 2016). Migration can also reach the oropharynx and can be detected on the surface or in the nucleus of tonsils (Pereira et al., 2008).

S. aureus have factors associated with virulence: capsule, catalase, leukotoxins, cytotoxins, enterotoxins (Levison 2016), coagulase, hyaluronidase (Tong et al., 2015), production of $\beta$-lactamase and components associated with biofilm formation (Murray et al.2009). These factors make the presence of S. aureusin the oropharynx, stimulating the development of tonsillitis in children (Zautneret al., 2010).

Understanding the colonization dynamics of the most incident bacteria, transmission routes, risk factors for infection progression and conditions that promote the appearance of bacterial resistance to antibacterials; will allow the optimization of strategies to effectively control the bacteria present in recurrent tonsillitis in children, contributing to significant improvement in the quality of life of affected patients. Thus, the objectives of this study were to analyze the profile of URT isolated from children with recurrent tonsillitis.

\section{Methodology}

This study deals with an experimental research (Köche, 2016; Pereira et al., 2018) for its methodological basement.

\subsection{Obtaining of the samples}

It is a laboratory research, the study was a cross-sectional observation from January to December of 2019, submitted to and approved by the Ethics Committee of the Clinical Hospital of the Federal University of Goiás (CEP/HC/UFG), under number 84908818.3.00005083.

To obtain the test samples, children who already had surgical indication for tonsil removal were selected who attended the Otorhinolaryngology Clinic of the Federal University of Goiás Hospital. The number of children chosen was based on the flow of surgeries that occurred in this clinic for tonsil removal per year. The sample number of was thirty patients. The samples were collected in three different sites of the URT, nasal cavity, oropharynx and nasopharynx; the samples were obtained before the surgical procedure of tonsillectomy, however, with one patient already sedated. As the children in the test group had undergone recent antibiotic therapy due to recurrent infections, four children who had not used antibacterial for ninety days and had surgical indication for adenoid hypertrophy only, with no infection present for a control group, were selected. Both samples were processed in the same way. 
The clinical specimen of the oropharynx was obtained with a swab, after opening the oral cavity, using a mouth opener, next to one of the anterior tonsillar pillars. The material of the nasal cavity was obtained with a $s w a b$, close to the inferior nasal concha, with the aid of a nasal speculum, to prevent contact with the nasal vestibule. In the nasopharynx, the sample was collected with a swab, through the mouth, moving the palate away. The swabs, duly identified, were introduced into Stuart transport medium, later; they were stored at room temperature and transported immediately for processing.

\subsection{Sample processing and standard plate counting}

For processing, the swabs containing the clinical specimens were inserted in $3 \mathrm{~mL}$ of brain heart broth (BHI). A $10^{1}$ dilution was performed, transferring an aliquot of $1 \mathrm{~mL}$ of $\mathrm{BHI}$ with the sample, to a test tube containing $9 \mathrm{~mL}$ of peptone water and subsequently homogenized.

An aliquot of $100 \mu \mathrm{L}$ of each dilution was sown, containing salt mannitol agar, GC (gonococcal) base agar, chocolate agar and blood agar. Samples shown on mannitol agar were incubated in aerobiosis at $37^{\circ} \mathrm{C}$ for 24 to 48 hours and samples in the other culture media were incubated in $\mathrm{CO} 2$ at $37^{\circ} \mathrm{C}$ for 24 to 48 hours.

After growth, morphocolonial characterization, counting and isolation of colonies on nutrient agar was carried out, with subsequent incubation. Then, the morphotintorial characterization and the $3 \%$ potassium hydroxide test $(3 \% \mathrm{KOH})$ were performed.

\subsection{Identification of the most incident URT bacteria}

After the morphotintorial analysis, the bacteria were subjected to biochemical tests for identification (Table 1), according to the National Health Surveillance Agency (2013) and Konemanet al. (2008).

Table 1. Biochemical evidence used to identify isolated colonizers.

\begin{tabular}{|c|c|c|c|c|c|c|}
\hline \multicolumn{7}{|c|}{ Staphylococcus aureus identification } \\
\hline $\begin{array}{l}\text { Catalase } \\
\text { Oxidase }\end{array}$ & $\begin{array}{l}\text { Coagulase } \\
\text { DNAse }\end{array}$ & $\begin{array}{l}\text { Hemolysis } \\
\text { Novobiocinsen } \\
\text { itivity }\end{array}$ & $\begin{array}{l}\text { ns } \\
\begin{array}{l}\text { NitrateAcet } \\
\text { oin Ureia }\end{array}\end{array}$ & $\begin{array}{l}\text { Arginine } \\
\text { Mannitol } \\
\text { Maltose }\end{array}$ & $\begin{array}{l}\text { Glucos } \\
\text { Lactose } \\
\text { Sucrose }\end{array}$ & $\begin{array}{l}\mathrm{NaCl} 10 \% \text { and } 15 \% \\
\mathrm{BHI} \text { a } 15^{\circ} \mathrm{C} \text { and } 45^{\circ} \mathrm{C}\end{array}$ \\
\hline \multicolumn{7}{|c|}{ Streptococcuspyogenesidentification } \\
\hline $\begin{array}{l}\text { CatalaseHemo } \\
\text { lysis }\end{array}$ & $\begin{array}{l}\text { Bile esculina } \\
\mathrm{NaCl} 6,5 \%\end{array}$ & \multicolumn{2}{|c|}{$\begin{array}{l}\text { Bacitracin Sensitivity Sensitivity } \\
\text { to TMP-SMZ* }\end{array}$} & \multicolumn{3}{|c|}{ CAMP/Hippuratehydrolysis } \\
\hline \multicolumn{7}{|c|}{ Streptococcuspneumoniaeidentification } \\
\hline Catalase & Hemolysis & OptochinSensit & itivity & Bile escul & & $\mathrm{NaCl} 6,5 \%$ \\
\hline \multicolumn{7}{|c|}{ Haemophilusinfluenzaeidentification } \\
\hline $\begin{array}{l}\text { Catalase } \\
\text { Oxidase }\end{array}$ & $\begin{array}{l}\text { Motility } \\
\text { Índole }\end{array}$ & $\begin{array}{l}\text { Ureia } \\
\text { Sucrose }\end{array}$ & $\begin{array}{l}\text { Bloodagar } \\
\text { Hemolysis }\end{array}$ & $\begin{array}{l}\text { MacConk } \\
\text { Lactose }\end{array}$ & yagar & Glucose \\
\hline \multicolumn{7}{|c|}{ Moraxellacatarrhalisidentification } \\
\hline Catalase & Oxidase & Motility & 3loodagar & FO/Glucose & & DNAse \\
\hline
\end{tabular}

*TMP-SMZ: trimethoprimsulfamethoxazole. Source: Authors.

Plaque counting was performed to estimate the number of bacteria in the original sample at each site studied. The calculation used was to take the number of colonies on the plate and multiply by the sample dilution index $=$ number of bacteria / $\mathrm{mL}$ (Tortora et al. 2012).

\subsection{Antibacterial sensitivity test}

Antibiogram tests were performed using the disk diffusion method. The choice of antibacterials was based on recommendations by the Institute of Clinical and Laboratory Standards (CLSI 2019). 
At first, a bacterial suspension in $0.85 \%$ saline solution was performed until turbidity, corresponding to the 0.5 MacFarland scale. A swab was embedded in this suspension and the sample was seeded on the surface of Mueller Hunton agar. Paper disks containing the selected antibiotics were placed on the agar surface. Subsequently, the plates were incubated at 37 ${ }^{\circ} \mathrm{C}$ for 18 hours. For the reading of the tests, the diameter of the inhibition halos was measured and the results were interpreted according to the CLSI (2019).

For S. aureus, Ciprofloxacin (CIP) $5 \mu \mathrm{g}$, Cefoxitin (CFO) $30 \mu \mathrm{g}$, Gentamicin (GEN) $10 \mu \mathrm{g}$, Penicillin (PEN) $10 \mu \mathrm{g}$, Clindamycin (CLI) $2 \mu \mathrm{g}$, Erythromycin (ERI) $15 \mu \mathrm{g}$, Sulfamethoxazole and associated trimethoprim (SUT) $30 \mu \mathrm{g}$, Linezolid (LNZ) $30 \mu \mathrm{g}$, Rifampicin (RIF) $5 \mu \mathrm{g}$ and Tetracycline (TET) $30 \mu \mathrm{g}$. The clindamycin resistance induction test, called the D test, was performed to detect resistance to macrolides, lincosamides and streptogramins. For this, the erythromycin and clindamycin discs were placed $15 \mathrm{~mm}$ apart and the result was considered positive when there was a flattening of the clindamycin inhibition halo, in the space among the erythromycin discs.

To evaluate the activity of $\beta$-lactamase resistance, mediated by the blaZ gene, the measure of the penicillin halo was considered. The isolates were indicative of enzymatic activity, with the formation of an inhibitory halo $\leq 29 \mathrm{~mm}$ in the penicillin disc, with bounded edges. Resistance to oxacillin mediated by the mecA gene was also evaluated, considering the measurement of the cefoxitin halo. Isolates with inhibition halo $\leq 21 \mathrm{~mm}$ were considered resistant to oxacillin / cefoxitin.

\subsection{Biofilm assay}

The biofilm assay was performed using microtiter plates according to the method of Tendolkaret al. (2004), with adaptations.

After the growth of bacteria on nutrient agar, the strains were inoculated in $4 \mathrm{~mL}$ of Trypticase soy broth (TSB), plus $1 \%$ glucose and incubated in aerobiosis for 18 hours at $37^{\circ} \mathrm{C}$. A $0.5 \mathrm{~mL}$ aliquot of the TSB broth with bacterial growth was transferred to another tube containing $4.5 \mathrm{~mL}$ of TSB $-10^{1}$ dilution. A total of $200 \mu \mathrm{L}$ of the dilution was transferred to a polystyrene microplate, U-bottom, with 96 wells.

The tests were performed in triplicate. For the negative control, $200 \mu \mathrm{L}$ of the TSB medium without inoculum were used, also in triplicate. For the positive control, strain of Pseudomonas aeruginosa PA01 was prepared, also in triplicate, according to the methodology performed for the samples of $S$. aureus to be tested. The plates were incubated at intervals of 24 hours and 48 hours, at $37^{\circ} \mathrm{C}$.

After the incubation period, samples were aspirated from each well, using a pipette with individual tips for each sample, so that there was no contamination. Then, with the aid of a pipette, each well was washed three times using phosphate buffered saline (PBS) solution, pH 7,2.

The plates were dried at room temperature for one hour. After drying, $200 \mu \mathrm{L}$ of methanol were deposited in each well and incubated for 15 minutes, to assist in fixation, subsequently the methanol was removed. The plate was kept at room temperature for further drying. A quantity of $200 \mu \mathrm{L}$ of $2 \%$ violet crystal was pipetted into each well and stored for five minutes. The removal was done and the wells were washed with distilled water, three times and, again left to dry at room temperature. To perform the reading, $200 \mu \mathrm{L}$ of methanol were pipetted into each well, submitted to the Enzyme-Linked Immunosorbent Assay (ELISA) reader.

The reading and interpretation of the biofilm formation test, was according to Stepanovićet al. (2007), with adaptations. An ELISA reader, model KHB ST 360, with a wavelength of $490 \mathrm{~nm}$ (nanometer) was used. The optical density of the isolates (DOi) was calculated by averaging the triplicate, buying the average obtained by the negative control (DOc). 
The result of reading the biofilm on a microplate was classified as: non-adherent if DOi $\leq \mathrm{DOc}$; weakly adherent if DOc $<$ DOi $\leq 2 \mathrm{X}$ DOc; moderately adherent if $2 \mathrm{X}$ DOc $<$ DOi $\leq 4 \mathrm{X}$ DOc; or strongly adherent, if DOi $>4 \mathrm{X}$ DOc.

\subsection{Amplification of the encoding gene for the 16S rRNA subunit}

The molecular identification of bacterial isolates started with the extraction of genomic DNA according to the methodology described by Van Soolingen and collaborators (1994). The integrity and purity of the DNA were evaluated in agarose gel at $1 \%$ and the concentration of DNA determined in NanoVue Plus UV-Vis (GE Healthcare ${ }^{\circledR}$ ) spectrophotometer. The genetic material was kept in a freezer at $-4{ }^{\circ} \mathrm{C}$ until preparation for sequencing. Then the amplification of the coding region for the 16S subunit was performed rRNA by PCR with the use of 27F universal primers (5'AGAGTTGATCCTGCTCAG-3')

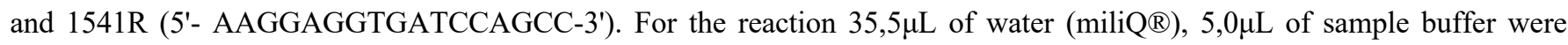
used. (10X) (Ludwig Biotec LTDA $\Re), 1,5 \mu \mathrm{L}$ of $\mathrm{MgCl} 2(50 \mathrm{mM})$ (Ludwig Biotec LTDA $\AA$ ), 1,0 $\mu \mathrm{L}$ of each primer solution $(10 \mathrm{mM})$ (InvitrogenTM $\mathbb{R}), 4,0 \mu \mathrm{L}$ of dNTP solution $(2,5 \mathrm{mM})$ (Ludwig Biotec LTDA $\left.{ }^{\circledR}\right), 1,0 \mu \mathrm{L}$ of Taq polymerase (5U)

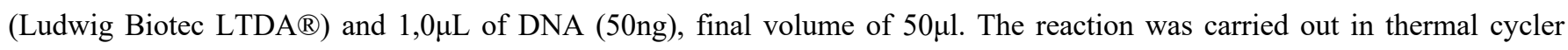
(Veriti ${ }^{\mathrm{TM}}$ 96-Well Thermal Cyclers ${ }^{\circledR}$ ) with the following cycling: $3 \mathrm{~min}$ initial denaturation at $94{ }^{\circ} \mathrm{C}$ and 30 denaturation cycles $94{ }^{\circ} \mathrm{C} / 1 \mathrm{~min}$, ringing $55{ }^{\circ} \mathrm{C} / 30$ s and extension $72{ }^{\circ} \mathrm{C} / 30$ s, extension final $72{ }^{\circ} \mathrm{C} / 10 \mathrm{~min}$. The product obtained from PCR was purified with the Agarose Extraction Kit (Cellco).

\subsection{Sequencing the $16 \mathrm{~S}$ rRNA coding region and analyzing the results}

Sequencing was performed using primers 27F, 1541R, 926F (5'-AAACTYAAAKGAATTGACGG3'), 530F (5'TGACTGACTGAGTGCCAGCMGCCGCGG-3'), 519R (5'- GTNTTACNGCGGCKGCT-GNGGCGNGG-3'), the sequencer used was ABI 3500 from Applied Biosystems ${ }^{\circledR}$ at Center for Biological Resources and Genomic Biology (CREBIO). The sequences obtained were analyzed using the Codon Code Aligner software (Codon Code Corporation) and compared for homology, with the GenBank NCBI database using BLASTn. The sequencesobtainedweredepositedat Gene Bank NCBI (Table2).

Table 2.Sequencedbacterialstrains.

\begin{tabular}{clc}
\hline Pacient & \multicolumn{1}{c}{ Bacteria } & Gene Bank \\
\hline 1 & Staphyloccocus aureus & MW480224 \\
2 & Staphyloccocus aureus & $\underline{\text { MW480226 }}$ \\
3 & Staphyloccocus aureus & $*$ \\
5 & Staphyloccocus aureus & $*$ \\
6 & Staphyloccocus aureus & $\underline{\text { MW480238 }}$ \\
7 & Staphyloccocus aureus & $*$ \\
14 & Staphyloccocus aureus & MW480542 \\
15 & Staphyloccocus aureus & MW480543 \\
16 & Staphyloccocus aureus & $*$ \\
18 & Staphyloccocus aureus & MW480559 \\
19 & Staphyloccocus aureus & $*$ \\
\hline
\end{tabular}

*Sequence not accepted for deposit due to insufficient size. Source: Authors.

The dendogram was obtained in the MegaX software from a set of DNA sequences by means of a computational method based on distance matrices. The distances were calculated through the Jukes and Cantor model and after calculating the 
distances and filling in the matrix the Neighbor-Joining algorithm were used to infer the similarity relations between the sequences. ClustalW alignments were also performed in the MegaX software.

\section{Results and Discussion}

Among a total of 30 children, 56.6\% (17/30), were male. The age of the patients who participated in the research ranged from four to 12 years, with a mean of 8.18 and a standard deviation of 2.6. The age and sex variables did not show any correlation, this is an indication of sample homogeneity.

The most incident bacterial species in URT were researched: Staphylococcus aureus, Streptococcus pyogenes, Streptococcus pneumoniae, Haemophilusinfluenzaeand Moraxella catarrhalis. In this study, the control group present only Staphylococcus spp. in two children and, another gender no researched in this study, was found on the other two children. It was possible to recover only S. aureus in $36.6 \%(11 / 30)$ of the test group patients, with variation between the three collection sites, as shown in Table 3.

Table 3.Isolation of Staphylococcus aureus according to the sites of the URT, in the studied patients.

\begin{tabular}{lccc}
\hline Patient & nasalcavity & nasopharynx & oropharynx \\
\hline 1 & $\mathrm{X}$ & $\mathrm{X}$ & $\mathrm{X}$ \\
2 & $\mathrm{X}$ & $\mathrm{X}$ & $\mathrm{X}$ \\
3 & $\mathrm{X}$ & - & - \\
4 & - & - & $\mathrm{X}$ \\
5 & $\mathrm{X}$ & - & $\mathrm{X}$ \\
6 & $\mathrm{X}$ & - & - \\
7 & $\mathrm{X}$ & - & $\mathrm{X}$ \\
8 & - & $\mathrm{X}$ & $\mathrm{X}$ \\
9 & - & $\mathrm{X}$ & $\mathrm{X}$ \\
10 & - & $\mathrm{X}$ & $\mathrm{X}$ \\
11 & $\mathrm{X}$ & - & - \\
\hline
\end{tabular}

Source: Authors.

According to the results obtained in this study, $S$. aureus was the most prevalent microorganism and its colonization was mainly in the oropharynx (8/11), followed by the nasal cavity (7/11) and nasopharynx (5/11). From these results, the other tests were developed with samples of $S$. aureus.

\subsection{Colony count of $S$. aureus at the evaluated sites}

For the colony forming unit (CFU) count at each evaluated site, a higher concentration of S. aureus can be seen in the oropharynx, followed by the nasal cavity (Table 4). 
Table 4. Colony forming unit (CFU) count at each evaluated site.

\begin{tabular}{cccc}
\hline Patients & \multicolumn{3}{c}{ CFU count*/MI } \\
\cline { 2 - 4 } 1 & Nasal Cavity & Nasopharynx & Oropharynx \\
2 & $5 \times 10^{1}$ & $1,5 \times 10^{2}$ & $1,5 \times 10^{2}$ \\
3 & $5 \times 10^{1}$ & 5 & $1,5 \times 10^{1}$ \\
4 & $8,5 \times 10^{1}$ & - & - \\
5 & - & - & $5 \times 10^{4}$ \\
6 & $1 \times 10^{2}$ & - & Countless \\
7 & $3,5 \times 10^{4}$ & - & - \\
8 & $5 \times 10^{4}$ & - & $1 \times 10^{2}$ \\
9 & - & $6 \times 10^{1}$ & $1,25 \times 10^{2}$ \\
10 & - & $2,5 \times 10^{1}$ & $5 \times 10^{1}$ \\
11 & - & $3,6 \times 10^{2}$ & $1,2 \times 10^{2}$ \\
\hline
\end{tabular}

*CFU: Colonyformingunit. Source: Authors.

\subsection{Antibacterial sensitivity test}

For the antibiogram test, 20 strains of $S$. aureus from the different sites surveyed were analyzed. According to the results (Figure 1), it was observed that $S$. aureus showed resistance mainly to antibacterials erythromycin 95\% (19/20), penicillin $85 \%(17 / 20)$, cefoxitin $85 \%$ (17/20) and ciprofloxacin 70\% (14/20). Virtually all strains were sensitive to sulfazotrim $90 \%(18 / 20)$, tetracycline $80 \%(16 / 20)$ and rifampicin $70 \%(14 / 20)$.

Figure 1. S. aureus susceptibility profile to the most commonly usedantibacterials in medical practice.

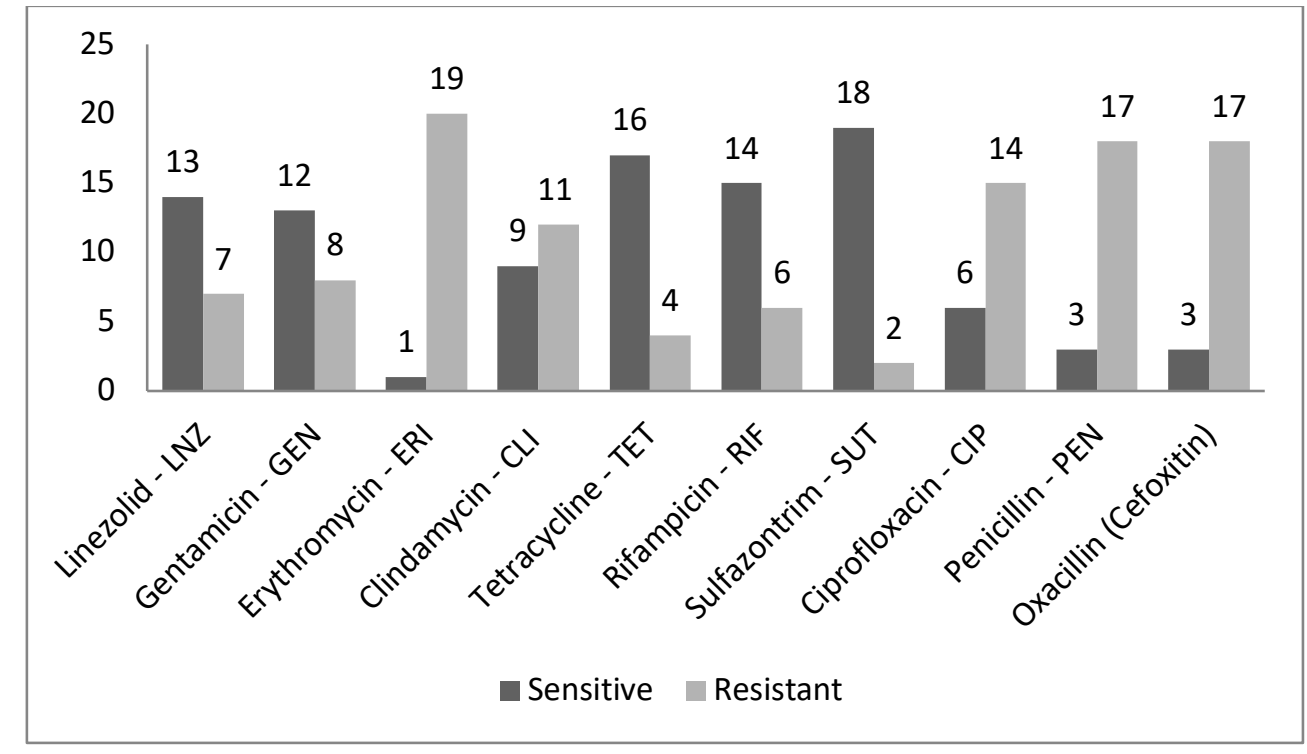

Source: Authors.

\subsection{Inducible resistance to clindamycin in clinical isolates of $S$. aureus}

In the antibiogram test, it was possible to detect the presence of inducible resistance to clindamycin by the D-test in $(30 \%)(6 / 20)$ of the tested S. aureus. 


\subsection{Capacity of $S$. aureus to form biofilm}

In the test to detect biofilm production, $100 \%$ (20/20) of S. aureus samples were positive for biofilm formation, with $80 \%(16 / 20)$ presenting moderate form and $20 \%(4 / 20)$ presenting strong form to biofilm. The anatomical sites were distributed equally in the biofilm formation; there was not a site that formed in a prevalent way.

\subsection{Sequencing the 16S rRNA}

We did the sequencing of $S$. aureus using the gene 16S rRNA. After confirming the $S$. aureus by sequencing, the sequence was analysed by NCBI and deposited on Gene Bank. On Table 5 are shown twosequences from genbank that presented higher identity with these study samples.

Table 5. Identity of S.aureus deposited on database and S. aureus of this study.

\begin{tabular}{ccc}
\hline Pacient & Gene Bank & SampleIdentity \% \\
\hline 1 & NR_037007.2 & $98.59 \%$ \\
2 & NR_037007.2 & $99.30 \%$ \\
3 & NR_037007.2 & $92.44 \%$ \\
4 & NR_037007.2 & $98.41 \%$ \\
5 & NR_037007.2 & $99.30 \%$ \\
6 & NR_037007.2 & $97.92 \%$ \\
7 & NR_037007.2 & $95.41 \%$ \\
8 & NR_037007.2 & $99.69 \%$ \\
9 & NR_037007.2 & $84.62 \%$ \\
10 & NR_037007.2 & $94.93 \%$ \\
11 & NR_037007.2 & $99.18 \%$ \\
\hline
\end{tabular}

Source: Authors.

The alignments (Figure 2A) corroborate with the results found in the dendogram, showing that the sequences that belong to the branches in common have a strong homology, this homology being represented by the *, characterizing that they have the same evolutionary ancestry.

Next to the branches (Figure 2B) is the percentage of replicated trees in which the associated taxons were grouped in the bootstrap test (500 replicas).

Based on the method used (Jukes and Cantor) this dendrogram was drawn in scale, so the length of the branches is in the same units of the evolutionary distances, so it is observed that the sequences obtained from the samples RF18 and RF15; OR5 and CN6; RF2 and CN7; OR6 and CN3; OR18 and OR16 are in very similar lengths of branches evidencing close evolutionary relations between such samples.Clades 93 and 96 showed a common evolutionary relationship. 
Figure 2: The alignments (A) show that the sequences have strong homology, the dendogram of genetic similarity (B) of bacterial isolates based on 16S rRNA genetic sequences.
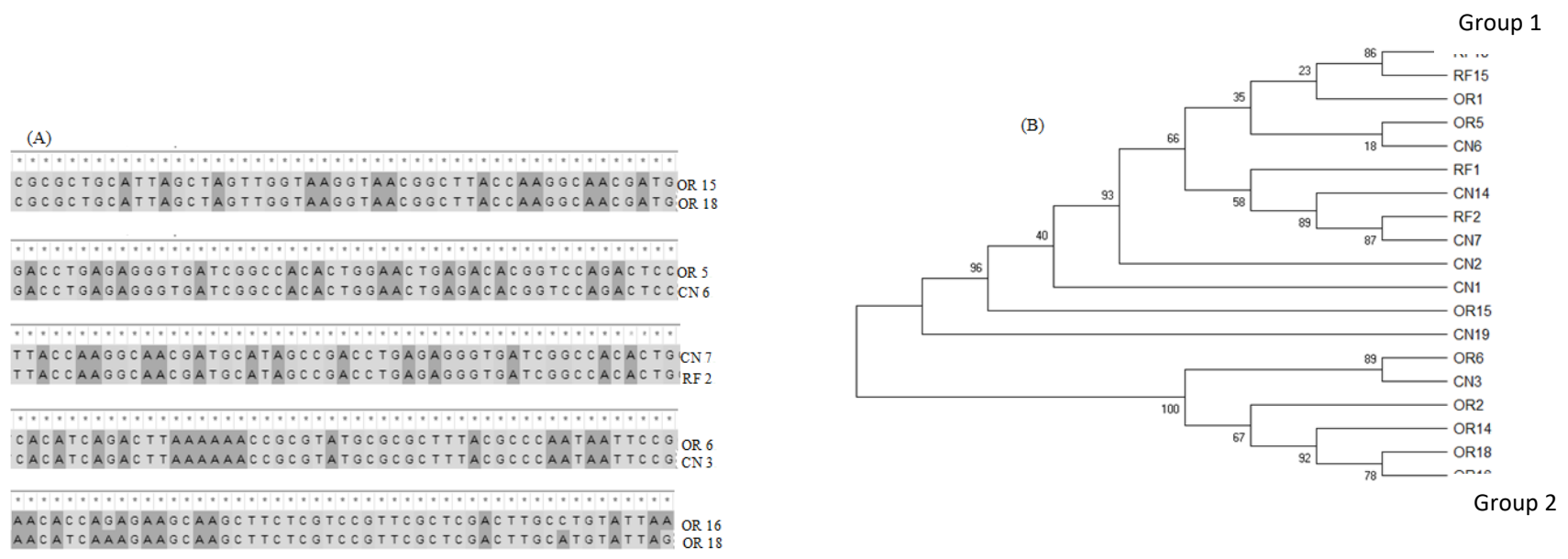

*The numbersrefertothepatient/OR:oropharynxCN:nasalcavityRF: rhinopharynx. Source: Authors.

\section{Discussion}

A research carried out in Hungary, evaluated the presence of the same pathogens from the present study in healthy children, a total of 580 children were evaluated with a surface swab, $210(36.20 \%)$ children were positive for at least one of the investigated microorganisms. Our control group has similar results as the number of children investigated in Hungary, according with the patient's history(Kovács et al., 2020).

The group A Streptococcus pyogenes is described as being responsible for tonsillitis in pediatric patients, being cited by many authors as the most important cause of infection (Sidell and Shapiro 2012; Pontin et al. 2016). A study carried out in Russia, with 54 pediatric patients undergoing tonsillectomy, for treatment of recurrent tonsillitis, identified the presence of $S$. pyogenes in 13\% (Boiko et al., 2018).

Another study carried out in Poland, with 71 pediatric patients, submitted to tonsillectomy for the treatment of recurrent tonsillitis, and demonstrated the presence of S. pyogenes in 8.3\% (Katkowska et al., 2017).

Published studies describe the prevalence of potentially pathogenic bacteria found in pediatric patients with recurrent tonsillitis, including Streptococcus pneumoniae, Streptococcus pyogenes, Staphylococcus aureus, Haemophilusinfluenzae and Moraxella catarrhalis (Kalaiarasi et al., 2018; Prates et al. 2018).

It is suggested that the decision to diagnose recurrent tonsillitis, be based on the patient's history and physical examination, that is, without a laboratory examination, it can not be said which bacteria is responsible for recurrent tonsillitis. In the present study, we did not have access to laboratory tests previously performed (Marinho, 2010).

In the present study, S. aureus was prevalent in this study, (36.6\%) of patients. Similar data were found by Gul et al. (2007), the researcher's isolated S. aureus in 38.4\% of 26 Turkish children. On the other hand,Katkowskaet al. (2020) isolated S. aureus in $45.1 \%$ of 71 Polish children. The two studies described, carried out a collection with a tonsil surface $s w a b$, like the one carried out in the present study.

The children volunteers of this study were surgically indicated, due recurrent tonsillitis. The predominant isolation of S. aureus corroborates the results published by Cavalcanti et al. (2019), who described the presence of $S$. aureus in patients with recurrent tonsillitis, suggesting that this bacterial species may be part of the etiology of recurrent tonsillitis.

A study carried out with children from New Zealand, demonstrated that S. aureus was present in a greater proportion in the nasal cavity regions (39\%) and in the oropharynx (32\%) (Berry et al., 2015). Similar data were isolated in this study, 
oropharynx (26.6\%) and nasal cavity (23.3\%). The nasal cavity is considered the primary anatomical site for colonization of $S$. aureus data confirmed in the present study; found the presence of the bacterium in $63.3 \%$ of the children involved (Verhoeven et al., 2012).

The nasopharynx was the site with the lowest incidence for $S$. aureus, these results are suggestive of the gradually decreasing transport, of this species from nasopharynx, after six weeks of the child's life. Justifying the beginning of a greater interaction with other colonizers in the region. As the child grows, the presence of $S$. aureus is replaced by mainly Streptococcus pneumoniae, Haemophilusinfluenzae and Moraxella catarrhalis(Blumentalet al., 2013).

The air, when entering through the nasal cavity, travels through the entire UTR until it reaches the lungs. It is known that the sites have an anatomical connection among them and the air works as a means of transportation causing microorganisms to move through these sites, being able to exchange genetic information that makes them have similarity (Kopf; Schneider; Nobs, 2015).

The use of antibacterial drugs causes the selection of resistant microorganisms to occur, in addition to promoting changes in the variety of microorganisms present in the individual's microbiota. Some studies suggest that, after antibiotic therapy, the microbiota can take years to recover completely. Even if antibiotic treatment is short-lived, the effects can be prolonged (Ursellet al. 2012).

A total of $81 \%$ of the patients involved in this study, due to recurrent tonsillitis, were previously sampled for this research, submitted to antibiotic therapy. The use of antibiotic therapy may have inhibited the growth of different colonizers, corroborated for the isolation of only $S$. aureus. To reinforce the aforementioned hypothesis, isolates of $S$. aureus, demonstrated the ability to form biofilm, which can be stimulated by the frequent use of antibiotics.

To reinforce the above hypothesis, isolates of $S$. aureus have demonstrated the ability to form biofilm, which can be stimulated by the frequent use of antibacterial, because as it is known within the biofilm there is a high density of bacterial cells, a factor that collaborates to the increase of the selection of bacteria that are present in the formation of the biofilm, because they can be selected under pressure of antibacterial, increase of the horizontal genetic exchange and increase of the frequency of mutation (Lazăr \& Chifiriuc 2010).

The biofilm presence in cases of $S$. aureus infection is described as a factor that makes the treatment difficult (Brackman et al., 2013). All isolates in the present study showed the ability to form biofilm, ranging from strong to moderate. This finding confirms the results of other studies, which also correlate the involvement of biofilm-forming S. aureus in cases of recurrent tonsillitis (Torrettaet al. 2013; Torrettaet al. 2015).

Amoxicillin is used as the first choice for the treatment of recurrent tonsillitis. In these situations, antibacterial resistance is mainly related to the use of $\beta$-lactams. Since 1970, there have been reports of therapeutic failures using amoxicillin. Therapeutic failures are justified by the bacterium producing the enzyme $\beta$-lactamase that inactivates the antibacterial action. This resistance mechanism is common to S. aureus (Pichichero, 1995; Katkowskaet al.,2017).

In the present study, patients used amoxicillin, amoxicillin + clavulanate, ampicillin + sulbactam and acetyl cefuroxime, all belonging to the class of $\beta$-lactams. The $S$. aureus isolated, showed greater resistance to erythromycin, penicillin, cefotaxime and ciprofloxacin. These drugs are macrolides, $\beta$-lactams and quinolones classes and have different mechanisms of action. The resistance mechanisms of $S$. aureus are efflux pump, modification of the target site and production of enzymes (Foster, 2017; Haaber et al., 2017; Vestergaard et al.,2019).

\section{Conclusion}

We conclude that $S$. aureus can be isolated from any of the studied sites, suggesting that the three sites should be used for the collection of clinical specimens in case of investigation. Antimicrobial resistance and the ability to form biofilms 
suggest that $S$. aureus contributes to recurrent tonsillitis. On the other hand, the chemical and physical resistance found in this study, may have contributed to bacteria recovering after the use of antibacterials, colonizing patients' microbiota more quickly compared to other colonizing species of the three anatomical sites.

Suggestions for future work is study a big number of the samples, to have a good perception of the microbiota that are located on tonsile

\section{Acknowledgments}

The author thanks the Coordination for the Improvement of Higher Education Personnel (CAPES), for the scholarship.

\section{References}

Berry, S., Morton, S., Atatoa Carr, P., Marks, E., Ritchie, S., Upton, A., \& Williamson, D., Grant, C., (2015). Colonisation with Staphylococcus aureus and Streptococcus pyogenes in New Zealand preschool children. New Zealand Medical Journal, 128, 60-67.

Blumental, S., Deplano, A., Jourdain, S., De Mendonça, R., Hallin, M., Nonhoff, C., Rottiers, S., Vergison, A., \& Denis, O., (2013). Dynamic pattern and genotypic diversity of Staphylococcus aureus nasopharyngeal carriage in healthy pre-school children. Journal Antimicrobial Chemotherapy, 68, $1517-1523$. https://doi.org/10.1093/jac/dkt080

Boiko, N. V, Kim, A. S., Stagnieva, I. V, Lodochkina, O. E., \& Filonenko, N. A., (2018). [The significance of antistreptolysin O characteristics for the determination of indications for tonsillectomy in the children]. Otorinolaringology journal, 83, 73-77. https://doi.org/10.17116/otorino201883473

Brackman, G., De Meyer, L., Nelis, H. J., \& Coenye, T., (2013). Biofilm inhibitory and eradicating activity of wound care products against Staphylococcus aureus and Staphylococcus epidermidis biofilms in an in vitro chronic wound model. Journal Applied Microbiology, 114, 1833-1842. https://doi.org/10.1111/jam.12191

Brazil, Ministry of Health. (2020). Database of the Unified Health System-DATASUS, Hospital Information System. Available in. http: // http://tabnet.datasus.gov.br/cgi/tabcgi.exe?sih/cnv/nruf.def. [Retrieved 07/07/2020].

Cavalcanti, V. P., Camargo, L. A. de, Moura, F. S., Melo Fernandes, E. J. de, Lamaro-Cardoso, J., Braga, C. A. da S. B., \& AndrÃ lcopyright, M. C. P. (2019). Staphylococcus aureus in tonsils of patients with recurrent tonsillitis: prevalence, susceptibility profile, and genotypic characterization. Brazilian J. Infect. Dis. $23,8-14$.

Coyte, K. Z., Schluter, J., \& Foster, K. R., (2015). The ecology of the microbiome: Networks, competition, and stability. Science, 350, 663-666. https://doi.org/10.1126/science.aad2602

Clinical and Laboratory Standards Institute- CLSI, (2019). Performance Standard for Antimicrobial Susceptibility Testing. twentieth new ed. Pennsylvania.

de Steenhuijsen Piters, W. A. A., Sanders, E. A. M., \& Bogaert, D., (2015). The role of the local microbial ecosystem in respiratory health and disease. Philosophical Transactions of the Royal Society B Biological Science, 370. https://doi.org/10.1098/rstb.2014.0294

Foster, T. J., (2017). Antibiotic resistance in Staphylococcus aureus. Current status and future prospects. FEMS Microbiology journal, 41, 430-449. https://doi.org/10.1093/femsre/fux007

Georgalas, C. C., Tolley, N. S., \& Narula, P. A., (2014). Tonsillitis. BMJ Clinical Evidence, 2014.

Infection Prevention and Control of Epidemic- and Pandemic-Prone Acute Respiratory Infections in Health Care. (2014). Guideline for World Health Organization - WHO. No. 5-9. Geneva.

Jiménez-Truque, N., Saye, E. J., Soper, N., Saville, B. R., Thomsen, I., Edwards, K. M., \& Buddy Creech, C., (2016). Longitudinal assessment of colonization with Staphylococcus aureus in healthy collegiate athletes. Journal Pediatric Infection Disease Socity, 5, 106-113. https://doi.org/10.1093/jpids/piu108

Johnston, J. J., \& Douglas, R., (2018). Adenotonsillar microbiome: an update. Postgrad Medical J. 94, 398_403. https://doi.org/10.1136/postgradmedj-2018135602

Kalaiarasi, R., Subramanian, K. S., Vijayakumar, C., \& Venkataramanan, R., (2018). Microbiological Profile of Chronic Tonsillitis in the Pediatric Age Group. Cureus 10. https://doi.org/10.7759/cureus.3343

Katkowska, M., Garbacz, K., \& Stromkowski, J., (2017). Staphylococcus aureus isolated from tonsillectomized adult patients with recurrent tonsillitis. APMIS, 125, 46-51. https://doi.org/10.1111/apm.12628

Köche, J. C. (2016). Fundamentos de metodologia científica. Editora Vozes.

Kovács, E., Sahin-Tóth, J., Tóthpál, A., van der Linden, M., Tirczka, T., \& Dobay, O., (2020). Co-carriage of Staphylococcus aureus, Streptococcus pneumoniae, Haemophilus influenzae and Moraxella catarrhalis among three different age categories of children in Hungary. PLoS One, 15, 1-21. https://doi.org/10.1371/journal.pone.0229021 
Research, Society and Development, v. 10, n. 15, e363101523181, 2021

(CC BY 4.0) | ISSN 2525-3409 | DOI: http://dx.doi.org/10.33448/rsd-v10i15.23181

Koneman, E. W., Allen, S. D. \& Janda, W. M., (2008). Microbiological diagnosis: text and colored atlas, sixth ed. Medical and Scientific.

Levinson, W, (2016). Medical Microbiology and Immunology, thirteenth ed. AMGH.

Murray, P. R., Rosenthal K. S., \& Pfaller, M. A. Medical microbiology. sixth ed.Elsevier.

Marinho, A. F., (1999). Amígdalas e adenóides - da infecção à obstrução. Revista Portuguesa de Otorrinolaringologia e Cirurgia Cérvico-Facial, 48 (1). 2532 .

National Health Surveillance Agency - ANVISA. (2013). Clinical Microbiology for Infection Control Related to Health Care. Guideline: Detection and identification of bacteria of medical importance. new ed. Anvisa.

Pereira, L.M.P., Juman, S., Bekele, I., Seepersadsingh, N., \& Adesiyun, A.A., (2008). Achado de bact ̃̃lcopyrightrias selecionadas em crianÃ $\backslash$ Sas de Trinidad com doen $\tilde{A} \backslash$ Sa amigdaliana crÃ $\backslash ’\{\}$ nica. Revista Brasileira de Otorrinolaringologia, 74, 903-911.

Sivaraman, K., Venkataraman, N., \& Cole, A.M., (2009). Staphylococcus aureus nasal carriage and its contributing factors. Future Microbiology, 4, 9991008. https://doi.org/10.2217/fmb.09.79

Tortora, G. J., Funke, B. R. \& Case, CL, (2017). Microbiology, tenth ed. Artmed.

Zautner, A. E., Krause, M., Stropahl, G., Holtfreter, S., Frickmann, H., Maletzki, C., Kreikemeyer, B., Pau, H. W., \& Podbielski, A., (2010). Intracellular persisting Staphylococcus aureus is the major pathogen in recurrent tonsillitis. PLoS One 5. https://doi.org/10.1371/journal.pone.0009452 